\title{
A Cyclic AMP Response Element Mediates Repression of Tyrosine Aminotransferase Gene Transcription by the Tissue-Specific Extinguisher Locus Tse-1
}

\author{
Michael Boshart," Falk Weih," Andrea Schmidt," \\ R. E. Keith Fournier, ${ }^{\dagger}$ and Günther Schütz* \\ * Institute of Cell and Tumor Biology \\ German Cancer Research Center \\ Im Neuenheimer Feld 280 \\ D-6900 Heidelberg \\ Federal Republic of Germany \\ I Division of Basic Sciences \\ Fred Hutchinson Cancer Research Center \\ 1124 Columbia Street \\ Seattle, Washington 98104
}

\section{Summary}

Tyrosine aminotransferase (TAT) gene expression is liver specific and inducible by glucocorticoids and via the CAMP signaling pathway. In fibroblasts and other nonliver cells the gene is subject to negative control by the trans-dominant tissue-specific extinguisher locus Tse-1. We identified a hepatocyte-specific enhancer that is repressed by Tse-1. Two distinct sequence motifs are absolutely essential for function of this enhancer: a CAMP response element (CRE), which is the target for repression by Tse-1, and a hepatocyte-specific element. The specificity of the enhancer is generated by the combination of these two essential elements, which are fully interdependent. In vivo footprinting indicates that Tse-1 acts by affecting protein binding at the CRE. A direct antagonism between Tse-1 and the CAMP signaling pathway suggests that Tse-1 plays a role in control of developmental activation of the TAT gene.

\section{Introduction}

Somatic cell fusion experiments provided the first evidence that diffusible factors acting in trans are involved in control of cell type-specific gene expression (for reviews see Davis and Adelberg, 1973; Davidson, 1974). Hybrid cells generated by fusing distinctly differentiated cells either fail to express tissue-specific gene products of either parent, a phenomenon termed extinction (Davidson et al., 1966; Schneider and Weiss, 1971; Sparkes and Weiss, 1973), or activate silent genes of one fusion partner (Peterson and Weiss, 1972; Brown and Weiss, 1975). This has been observed in both heterokaryons and proliferating hybrid cells (Mevel-Ninio and Weiss, 1981; Blau et al., 1985). Killary and Fournier (1984) have shown that extinction in hepatoma $\times$ fibroblast hybrids has a specific genetic basis. They have defined a locus on mouse fibroblast chromosome 11 and its human homolog 17, the tissue-specific extinguisher 1 (Tse-1), which represses hepatoma-specific expression of tyrosine aminotransferase (TAT). Tse-1 is not syntenic with the structural gene encoding mouse TAT that has been mapped to chromosome 8 (Müller et al., 1985). In monochromosomal hybrids expression of the
TAT structural genes of both parental cell types is determined by the presence or absence of fibroblast Tse- 1 (Peterson et al., 1985). TAT expression is equally extinguished in hepatoma microcell hybrids containing chromosome 11 from several other mouse donor cell lines derived from any of the three primary germ layers (Gourdeau et al., 1989). Together, this suggests a role for Tse-1 in control of liver-specific expression of TAT.

Regulation by Tse-1 is highly target gene specific. Only a subset of liver-specific genes, including TAT, is coordinately repressed by Tse-1 (Lem et al., 1988; Thayer and Fournier, 1989; Ruppert et al., 1990). These target genes share additional characteristics of regulation. They are all inducible via the cAMP pathway and by glucocorticoids, and their expression is dependent on the presence of a second regulatory locus residing on mouse chromosome 7 (see Ruppert et al., 1990). In karyotypically complete hepatoma $\times$ fibroblast hybrids virtually all liver-specific traits are extinguished (Chin and Fournier, 1987). This suggests the existence of additional extinguisher loci regulating distinct sets of liver-specific genes. A locus residing on mouse chromosome 1 , termed Tse-2, represses expression of serum albumin and alcohol dehydrogenase (Petit et al., 1986; Chin and Fournier, 1989).

Nothing is known to date about the products of extinguisher loci. As these trans-dominant factors are defined by genetic experiments, which allow identification of regulatory factors not necessarily binding to DNA, it is particularly attractive to investigate their mechanism of action. Since Tse-1 exerts its effect largely through transcriptional control (A. F. Stewart and E. Schmid, unpublished data), we have decided to approach the underlying mechanisms by determining the cis-acting sequences mediating repression of rat TAT gene transcription by Tse-1.

The TAT gene also provides an excellent model to study how cell type-specific factors and hormonal signal transduction pathways interact and control the correctly timed establishment of liver-specific gene expression. TAT expression is restricted to parenchymal cells of the liver (Hargrove and Granner, 1985). Transcription of the gene can be induced by glucocorticoids and by glucagon acting via the CAMP pathway (Granner and Beale, 1985; Hashimoto et al., 1984; Schmid et al., 1987). TAT expression is undetectable before birth but increases rapidly within the first hours after birth (Greengard, 1970). Levels of glucocorticoids and hormones acting via the CAMP pathway also increase in the newborn, owing to postnatal hypoglycemia. These hormones seem to play a role in triggering the developmentally programmed onset of expression, as premature activation of the TAT gene can be elicited by administration of glucagon (acting via cAMP) in utero and this effect is enhanced by glucocorticoids (Greengard, 1970; Ghisalberti et al., 1980; Ruiz-Bravo and Ernest, 1982).

A link between control of cell type-specific transcription and hormonal signal transduction was suggested by the observation that induction via the CAMP pathway could re- 
verse repression by Tse-1 in monochromosomal hepatoma hybrids (Thayer and Fournier, 1989; Ruppert et al., 1990). Here we show that Tse-1 represses the activity of a hepatocyte-specific enhancer that we identified $3.6 \mathrm{~kb}$ upstream of the start site of TAT transcription. A cAMP response element (CRE), which is an essential component of this enhancer, mediates repression by Tse-1.

\section{Results}

\section{A Hepatocyte-Specific Element Is Located Far Upstream of the TAT Promoter}

To identify cis-acting sequences important for restriction of TAT gene transcription to hepatocytes, we performed gene transfer into several cell lines of either hepatic, epithelial, or mesenchymal origin. The TAT gene is expressed in the well-differentiated rat hepatoma cell line FTO-2B (Killary et al., 1984; Killary and Fournier, 1984) at a rate similar to that in liver. The rat hepatoma line HTC (Thompson et al., 1966) shows approximately 10-fold lower levels of TAT mRNA than FTO-2B. In both cell lines TAT transcription can be induced by glucocorticoids, but only in FTO-2B does it respond to induction via the CAMP pathway. Neither the human hepatoma line HepG2 (Knowles et al., 1980), the human cervical adenocarcinoma line HeLa, nor the rat fibrosarcoma cell line XC (Svoboda, 1960) expresses detectable amounts of TAT (data not shown). Thus, high level expression of the TAT gene is restricted to differentiated hepatoma cell lines, which reflects hepatocyte-specific expression observed in vivo.

DNAase I hypersensitive site mapping had indicated the presence of a hypersensitive site $3.6 \mathrm{~kb}$ upstream of the start site of transcription of the TAT gene in chromatin from liver and differentiated hepatoma cells, but not from nonexpressing kidney cells or fibroblasts (D. Nitsch, A. F. Stewart, M. B., R. Mestril, F. W., and G. S., submitted). Expression of a TATCAT (CAT = chloramphenicol acetyltransferase) fusion construct encompassing 3341 bp of TAT upstream sequences (TATCAT $-3341 /+62$ ) was low in all five cell lines as compared with CAT expression driven by the herpes simplex virus thymidine kinase (HSV TK) promoter. With construct TATCAT $-3922 /+62$ we noted a more than 50-fold increase in CAT expression in the welldifferentiated rat hepatoma line FTO-2B, but no change in any of the other cell lines (Table 1). This suggests an important role of the region between -3922 and -3341 in control of liver-specific expression of the TAT gene.

\section{TAT Regulatory Sequences Are Responsive to the Product of the Tissue-Specific Extinguisher Locus Tse-1}

As the tissue-specific extinguisher locus Tse-1 is thought to play an important role in restricting TAT expression to cells of hepatic origin, we asked whether a TATCAT fusion construct including the hepatocyte-specific element would respond to the presence of Tse-1. To this end, we made use of cell lines constructed by microcell fusion of human chromosome 17 derived from fibroblasts with a subclone of the rat hepatoma line FTO-2B (Lem et al., 1988; Leach et al., 1989). The resulting cell line $7 A E 27$ retains several

\begin{tabular}{|c|c|c|c|c|c|}
\hline \multirow[b]{2}{*}{ Construct } & \multicolumn{5}{|c|}{$\begin{array}{l}\text { Relative CAT Activity in Extracts from } \\
\text { Transfected Cell Lines }\end{array}$} \\
\hline & FTO-2B & HTC & $\mathrm{xC}$ & HepG2 & Hela \\
\hline pBLCAT2 ${ }^{\circ}$ & 100 & 100 & 100 & 100 & 100 \\
\hline TATCAT $-3341 /+62$ & 35 & 13 & 4 & 19 & 25 \\
\hline TATCAT $-3922 /+62$ & 1941 & 14 & 3 & 17 & 30 \\
\hline
\end{tabular}

a FTO-2B cells were transfected by lipofection (see Experimental Procedures). All other cell lines were electroporated under identical conditions (see Experimental Procedures). A luciferase expression vector (RSVlucA/H) was included as internal reference. After $50 \mathrm{hr}$, extracts were prepared and assayed for CAT and luciferase activity. Relative CAT activity was calculated by correcting CAT expression for luciferase expression and setting the activity of pBLCAT2 arbitrarily to 100 for each cell line. Absolute values for pBLCAT2 are $0.6 \mathrm{pmol} / \mathrm{min}$ per $\mathrm{mg}$ in $\mathrm{FTO}-2 \mathrm{~B}, 19 \mathrm{pmol} / \mathrm{min}$ per $\mathrm{mg}$ in $\mathrm{HTC}, 395 \mathrm{pmol} / \mathrm{min}$ per $\mathrm{mg}$ in XC, $12 \mathrm{pmol} / \mathrm{min}$ per $\mathrm{mg}$ in $\mathrm{HepG} 2$, and $10 \mathrm{pmol} / \mathrm{min}$ per $\mathrm{mg}$ in HeLa cells. Data from representative transfection experiments are shown throughout this paper. Each construct has been tested in at least three independent experiments, using two different plasmid preparations in most cases.

HSV TK promoter fused to CAT (Luckow and Schütz, 1987).

markers from the long arm of human chromosome 17 including the Tse- 1 locus and expresses the human Tse- 1 product on a rat hepatoma background. As a control, we used 7AD7, which retains most of these markers on the same hepatoma background but lacks the Tse-1 locus. This cell line displays identical properties as the parental line FTO-2B. A construct encompassing 4289 bp of TAT upstream sequences (TATCAT $-4289 /+62$ ) was transfected into these cell lines along with a number of control plasmids that should not respond to Tse-1. The SV40 enhancer/ promoter, the Rous sarcoma virus long terminal repeat (RSV LTR), and the HSV TK promoter are known to be active in many cell types. Expression of $\alpha_{1}$-antitrypsin and albumin is liver specific, but these genes do not respond to Tse-1 (Killary and Fournier, 1984; R. E. K. F., unpublished data). As expected, we found the levels of expression of the various control constructs almost identical in the two cell lines 7AD7 (Tse-1 ${ }^{-}$) and 7AE27 (Tse-1 ${ }^{+}$) (Table 2). Only expression of TATCAT $-4289 /+62$ was about 60 fold reduced in 7AE27 (Tse-1 ${ }^{+}$). This dramatic and genespecific inhibition of CAT expression correlates with the presence of Tse-1 activity, suggesting that TAT upstream sequences include a Tse- 1 response element.

It had previously been noted that induction via the cAMP pathway could antagonize the Tse- 7 effect on TAT gene expression in hepatoma microcell hybrids (Thayer and Fournier, 1989). Therefore, in the experiment presented in Table 2 we included inductions with forskolin, a drug that activates adenylate cyclase and thereby raises intracellular CAMP levels (Seamon et al., 1981). We noted only a minor effect of forskolin treatment on expression of TATCAT $-4289 /+62$ in the control cell line 7AD7 (Tse-1 ${ }^{-}$), but an approximately 75 -fold induction of CAT expression from this construct in the presence of Tse-1 (in 7AE27). The induced level of expression in 7AE27 $\left(\right.$ Tse- $\left.1^{+}\right)$was close to 
Table 2. Repression by Tse-1 Is Highly Target Specific

\begin{tabular}{|c|c|c|c|c|c|c|}
\hline \multirow[b]{3}{*}{ Construct } & \multicolumn{6}{|c|}{ Relative CAT Activity in Extracts from Transfected Cell Lines ${ }^{\mathrm{a}}$ : } \\
\hline & \multicolumn{3}{|c|}{ 7AD7 $\left(\right.$ Tse-1 $\left.^{-}\right)$} & \multicolumn{3}{|c|}{ 7AE27 $\left(\right.$ Tse- $\left.1^{+}\right)$} \\
\hline & Uninduced & $10 \mu \mathrm{M}$ Forskolin & Fold & Uninduced & $10 \mu \mathrm{M}$ Forskolin & Fold \\
\hline pSV2cat ${ }^{b}$ & 100 & 69 & 0.7 & 100 & 83 & 0.8 \\
\hline pRSVCAT & 1324 & 1416 & 1.1 & 857 & 1278 & 1.5 \\
\hline pBLCAT2 & 38 & 34 & 0.9 & 49 & 86 & 1.8 \\
\hline pTK14C & 3860 & 3964 & 1.0 & 3006 & 2705 & 0.9 \\
\hline $\begin{array}{l}\text { Human } \alpha_{1} \text {-antitrypsin } \\
\qquad 1200 /+44^{e}\end{array}$ & 39 & 37 & 1.0 & 44 & 38 & 0.9 \\
\hline Rat albumin $-151 /+4^{t}$ & 20 & 33 & 1.6 & 15 & 47 & 3.0 \\
\hline TATCAT $-4289 /+62$ & 355 & 540 & 1.5 & 6 & 466 & 75 \\
\hline
\end{tabular}

a Duplicate plates were transfected by lipofection (see Experimental Procedures). RSVlucA/H was included as internal reference. Twenty-two hours prior to harvest one plate was induced with $10 \mu \mathrm{M}$ forskolin; the other was treated with $0.1 \%$ ethanol as solvent control. The total expression period was $65 \mathrm{hr}$. CAT activity was corrected for luciferase activity and for protein and is given as relative activity, arbitrarily setting the activity of pSV2cat to 100 . Absolute values for uninduced pSV2cat are $1.2 \mathrm{pmol} / \mathrm{min}$ per $\mathrm{mg}$ in $7 \mathrm{AD} 7$ and $2.7 \mathrm{pmol} / \mathrm{min}$ per $\mathrm{mg}$ in $7 \mathrm{AE} 27 \mathrm{cells}$.

b SV40 enhancer/promoter fused to CAT (Gorman et al., 1982).

c RSV LTR fused to CAT (Gorman et al., 1982).

a Two copies of the SV40 enhancer in front of the TK promoter (R. Miksicek and G. S., unpublished data).

e Ciliberto et al. 1985.

' Heard et al., 1987.

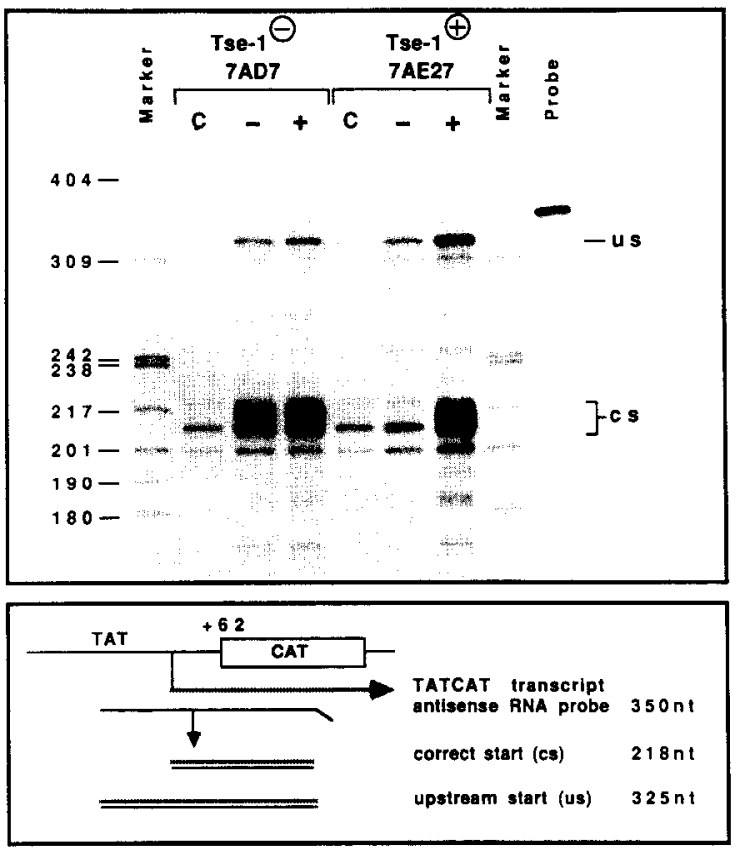

Figure 1. Start Site Mapping of TATCAT mRNA

TATCAT $-4289 /+62$ was introduced into 7AD7 (Tse-1 ${ }^{-}$) and 7AE27 $\left(T s e-1^{+}\right)$cells by lipofection as described in Experimental Procedures. Cells were split onto duplicate plates $20 \mathrm{hr}$ after transfection. Thirty hours after splitting, the cells were induced with $10 \mu \mathrm{M}$ forskolin or treated with $0.1 \%$ ethanol as solvent control in serum-free medium. RNA was extracted $67 \mathrm{hr}$ after addition of the DNA-lipid complex. One hundred micrograms of total RNA from untransfected, uninduced control cells (c), and uninduced $(-)$ and induced $(+)$ transfected cultures was hybridized to $10 \mathrm{fmol}\left(1.6 \times 10^{5} \mathrm{dpm}\right)$ of a uniformly labeled, gelpurified antisense riboprobe overlapping the start site of transcription. The samples were digested with RNAase $A$ and $T_{1}$ and loaded onto an $8 \%$ polyacrylamide-urea gel. The size of Hpall-cut pBR322 marker fragments is given in base pairs on the left. The expected fragments protected trom RNAase digestion are shown in the diagram with their calculated sizes. The autoradiogram was exposed for $12 \mathrm{hr}$. Weak bands in the untransfected control lanes may result from incomplete digestion of the probe. the level measured in 7AD7 (Tse-1-). Thus, raised intracellular levels of cAMP reverse the Tse-1 effect. In the hybrid clone 7AE27, full reversion of Tse-1-mediated repression of the endogenous TAT gene required combined induction via the CAMP pathway and by glucocorticoids (see Ruppert et al., 1990). This was not observed for the transfected constructs.

To ascertain that the observed effects on CAT expression were due to changes in abundance of CAT mRNA correctly initiated at the start site of TAT gene transcription, we performed a ribonuclease protection experiment with RNA of transfected 7AD7 (Tse-1 ${ }^{-}$) and 7AE27 (Tse-1 ${ }^{+}$) cells. The relative abundance of correctly initiated TATCAT transcripts was in good agreement with the values obtained from CAT enzymatic assays (Figure 1).

\section{A Hepatocyte-Specific Enhancer 3.6 kb Upstream of the TAT Promoter is a Target for Tse-1 Action} To determine the boundaries of the hepatocyte-specific element far upstream of the TAT promoter (see Table 1), we constructed a series of $5^{\prime}$ and $3^{\prime}$ internal deletion mutants (TATCAT series, Figure 2A). With deletions from the $5^{\prime}$ end, CAT activity in 7AD7 (Tse-1 ${ }^{-}$) cells decreased in two steps, about 2-fold between -3816 and -3709 and about 50 -fold between -3661 and -3628 . No further decrease was observed between -3628 and -351 , indicating that the residual activity of TATCAT $-3628 /+62$ reflected the basal activity of the TAT promoter (data not shown). Internal deletions from the 3 ' side of the relevant region (starting from -3341 ) led to a dramatic loss of activity between -3581 and -3589 . Thus, an essential region designated domain $B$ in Figure $2 B$ could be localized between -3661 and -3581 . Any further deletion into this 80 bp fragment led to total loss of enhancer function, and CAT expression was reduced to the basal level of the TAT promoter. The region downstream of -3581 , contributing a moderate effect, was designated domain $C$ in Figure 2B. 


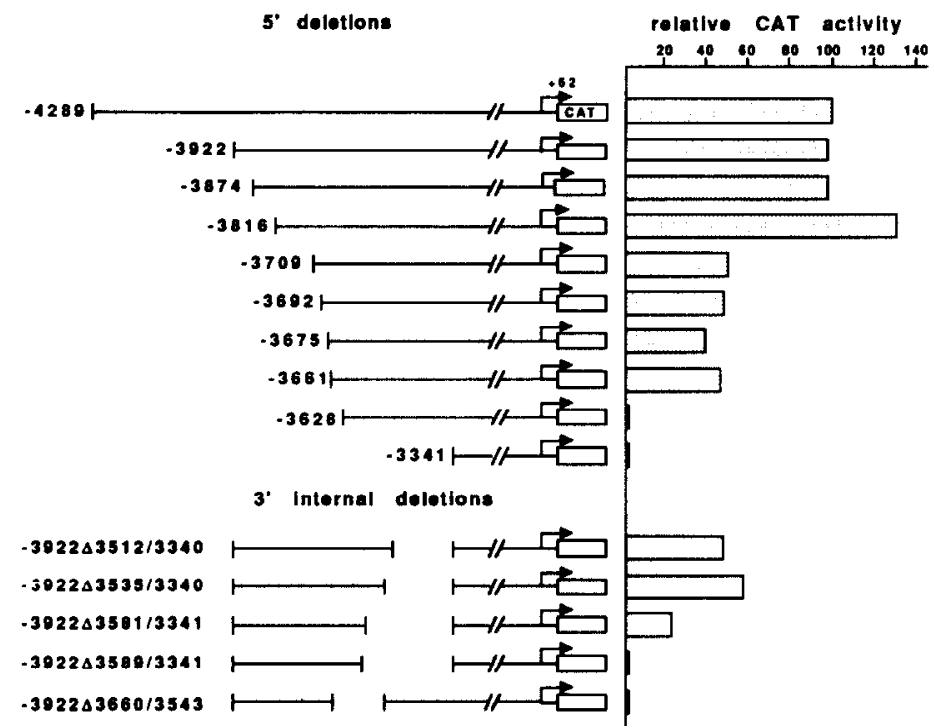

$\mathbf{B}$

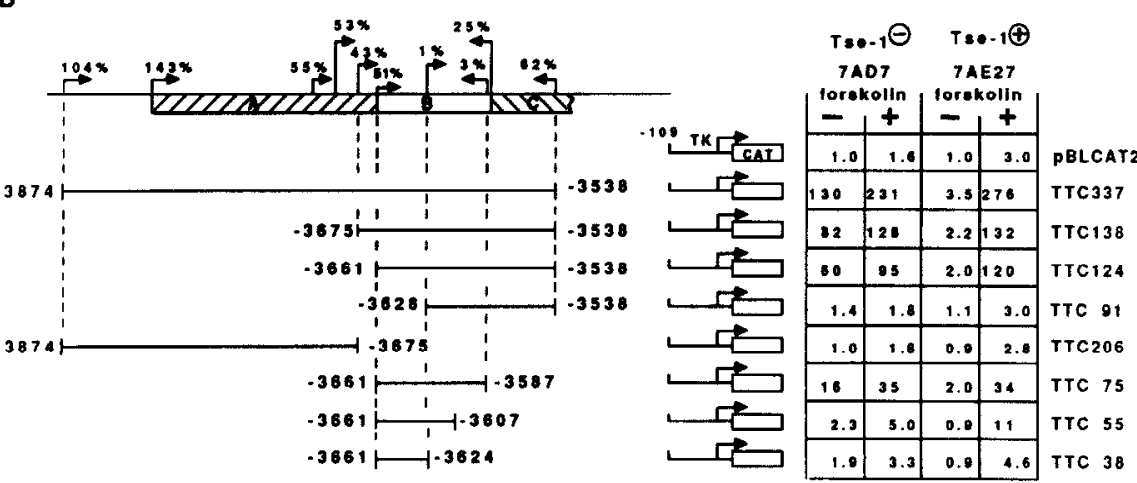

Figure 2. Deletion Analysis of the Cell Type-Specific Enhancer

(A) The $5^{\prime}$ and $3^{\prime}$ internal deletion constructs shown in the diagram were transfected into $7 A D 7$ (Tse-1') cells by lipofection (see Experimental Procedures). As internal reference, RSVlucA/H was included. Seventeen hours after addition of the DNA-lipid complex, medium was changed and incubation continued in serum-free medium. Cellular extracts were prepared after $63 \mathrm{hr}$ and assayed for CAT and luciferase activity. Luciferase-corrected CAT activity was calculated as relative activity by arbitrarily setting the value of the largest construct (TATCAT $-4289 /+62,180 \mathrm{pmol} / \mathrm{min}$ per $\mathrm{mg}$ ) to 100 . Numbers to the left of the diagram indicate the deletion endpoints in base pairs relative to the start site of transcription.

(B) In the upper part of the diagram, domains A, B, and C of the enhancer are shown as deduced from the data presented in (A). For comparison, endpoints of the $5^{\prime}$ and $3^{\prime}$ internal deletion constructs used in (A) are indicated as arrows pointing to the right ( $5^{\prime}$ deletions) or to the left $\left(3^{\prime}\right.$ deletions). The relative CAT activities taken from (A) are indicaled on top of the arrows. Subfragments from the enhancer region, which were placed in sense orientation in front of the TK promoter, are drawn as thin lines. Numbers to the left and right of these lines indicate the position of the first or last base pairs of TAT sequence relative to the start site of transcription.

These constructs (TTC series) were transfected into 7AD7 (Tse-1 $1^{-}$) and 7AE27 (Tse-1 $1^{+}$) cells by lipofection. Twenty hours after addition of the DNA-lipid complex, cells were split onto duplicate plates, incubated for $5 \mathrm{hr}$ in serum-containing medium to allow attachment to the culture dish and then induced in serum-free medium with $10 \mu \mathrm{M}$ forskolin (plus sign in the table) or $0.1 \%$ ethanol as solvent control (minus sign in the table). Cells were harvested after a total expression period of $63 \mathrm{hr}$. CAT activity was determined, corrected for protein, and is given in the table as fold stimulation of the uninduced TK promoter in pBLCAT2, arbitrarily set to 1 . Absolute values for pBLCAT are $0.75 \mathrm{pmol} / \mathrm{min}$ per $\mathrm{mg}$ in $7 \mathrm{AD7}$ and 0.74 $\mathrm{pmol} / \mathrm{min}$ per $\mathrm{mg}$ in $7 \mathrm{AE} 27$.

The weak effect contributed by sequences between -3661 and -3816 defined domain $A$. Domains $A$ and $C$ were both dependent on an intact domain $B$ and were not further investigated.

A hepatocyte-specific positive element seemed to us a likely target of Tse- 1 action. Therefore, we placed a $337 \mathrm{bp}$ restriction fragment spanning domains $A, B$, and part of $C$ in front of the heterologous HSV TK promoter and assayed this construct (TTC337) in the cell lines 7AD7 (Tse$\left.1^{-}\right)$and 7AE27 (Tse-1 ${ }^{+}$) with or without induction by forskolin (Figure 2B). The TAT sequences stimulated the TK promoter about 130 -fold in 7AD7 (Tse-1 ${ }^{-}$) but only weakly responded to forskolin. In the presence of Tse-1 (in 7AE27 cells) hardly any effect of these TAT sequences on the TK promoter was seen in uninduced cells, whereas forskolin induced expression approximately 80 -fold. The element was equally active in both orientations in front of the TK promoter and was independent of distance in front of both the TAT and TK promoters (data not shown). Thus, Tse-1 acts via a hepatocyte-specific enhancer. Smaller subfragments from the enhancer region were then tested in front of the TK promoter (Figure $2 \mathrm{~B}$ ). The results were in agree- 

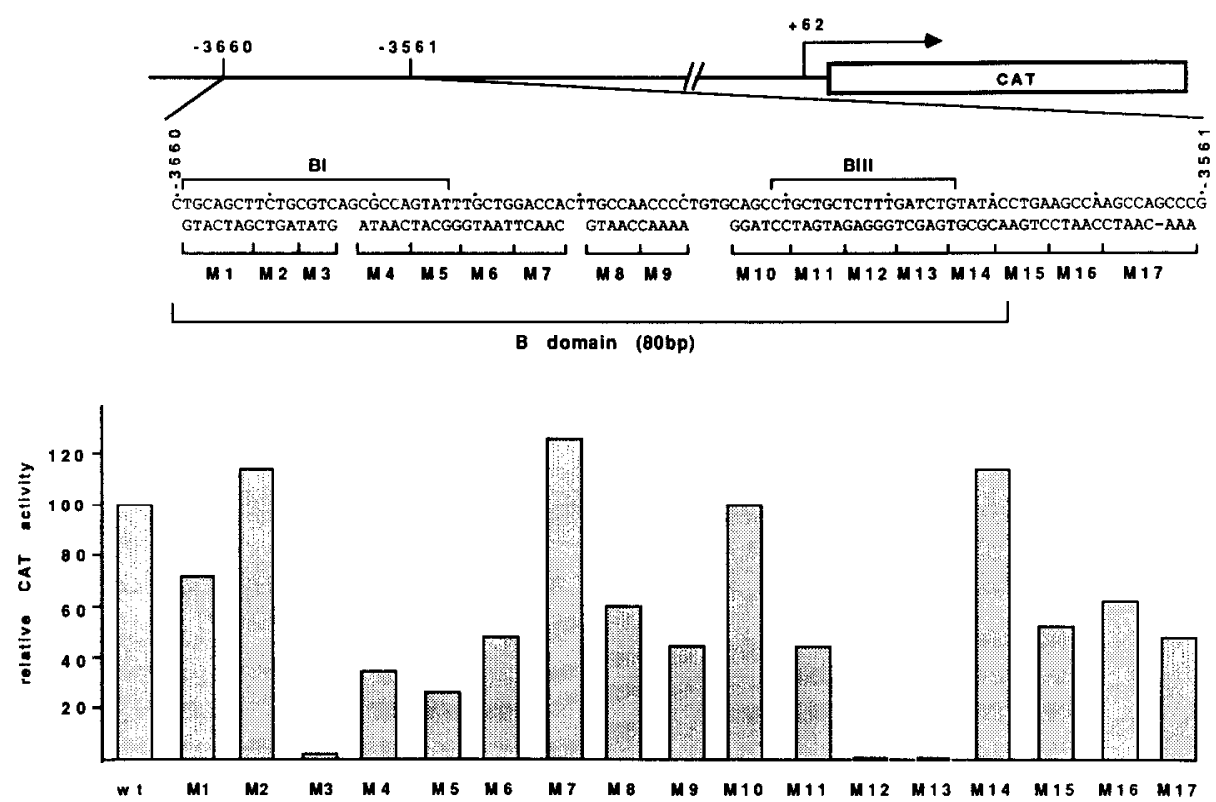

Figure 3. Scan of Clustered Point Mutations through Domain B of the Enhancer

(Top) The TAT upstream sequence from -3561 to -3660 is shown. The positions of 17 clustered point mutations and the respective mutant sequences are indicated by brackets. Above the sequence, brackets mark the positions of synthetic oligonucleotides BI and BIII.

(Bottom) 7AD7 (Tse-1 ) cells were transfected by lipofection (see Experimental Procedures) with the wild-type (Wt) construct TATCAT -4289/+62 or the 17 mutants (M1 to M17). RSVlucA/H was included as internal reference. Cells were kept in serum-free medium throughout the expression period of $65 \mathrm{hr}$. CAT activity was corrected for luciferase activity and is given as relative activity, arbitrarily setting the wt construct to 100 . The absolute value for the wt construct is $216 \mathrm{pmol} / \mathrm{min}$ per $\mathrm{mg}$.

ment with the deletion analysis of the enhancer in its natural position $3.6 \mathrm{~kb}$ upstream of the TAT promoter. Most importantly, all fragments retaining enhancer activity were repressed by Tse-1 and were strongly inducible with forskolin in the presence of Tse-1. We conclude that the sequences essential for enhancer function, repression by Tse-1, and reversal of Tse- 1 repression by CAMP all map to domain $\mathrm{B}$.

\section{A CRE-Like Sequence and a Second Motif Are Both Essential for Enhancer Function}

To dissect the elements responsible for this complex regulation, we carried out a systematic scan with clustered point mutations through domain B of the TAT enhancer. Transversion mutations were generated in their natural position $3.6 \mathrm{~kb}$ upstream of the TAT promoter and were tested in 7AD7 ( Tse-1 $^{-}$) cells (Figure 3). We detected two distinct motifs that are absolutely essential for enhancer function. Three base changes in mutant $\mathrm{M} 3$ led to a 40 -fold decrease in activity. Mutation of a second motif defined by M12 and M13 also reduced enhancer function about 50fold, which is equivalent to total deletion of the enhancer (see Figure 2A). Therefore, this cell type-specific enhancer shows little redundancy of elements. Furthermore, the two essential regions are interdependent. The $\mathrm{BI}$ motif mutated in $M 3$ resembles CREs of several genes (Comb et al., 1986; Montminy et al., 1986; Delegeane et al., 1987; Silver et al., 1987; Tsukada et al., 1987; Quinn et al., 1988; Fisch et al., 1989). In mutant M2 we changed the CRE-like motif to a perfect CRE consensus sequence (CTGACGTCAG). The neutral phenotype of M2 is in agreement with the observation that the TAT motif is a functional CRE (see below and F. W., A. F. Stewart, M. B., D. Nitsch, and G. S., submitted). We noted similarity of the BIII motif to the binding sites for hepatoma-specific factors in the enhancer of the human hepatitis B virus (Shaul and Ben-Levy, 1987) and to sequences in the liver-specific core promoter region of the human hepatitis B virus (Yee, 1989).

We have tested the same set of mutants in the presence of Tse-1. None of our mutants affected negative regulation by Tse-1 (data not shown). This suggests that repression by $T s e-1$ is mediated by sequences identical to or overlapping with one or both of the motifs essential for basal enhancer function.

The Two Essential Motifs Cooperate and Together Are Sufficient to Confer the Regulatory Properties of the Enhancer

To test the two essential motifs individually, we had to overcome their interdependence. Therefore, we cloned tandem dimers of the oligonucleotides shown in Figure 3, designated $\mathrm{BI}$ and $\mathrm{BIII}$, in front of the HSV TK promoter. In addition, mutant versions of the $\mathrm{Bl}$ dimer were made. These constructs were transfected into 7AD7 (Tse-1-) cells, and CAT activity was measured from uninduced or forskolin-induced cultures (Figure 4). The BI dimer, which includes the CRE-like motif, clearly behaves as a CRE, with about 9-fold stimulation of the TK promoter upon forskolin treatment. The reverse orientation of the BI dimer conferred cAMP responsiveness to an equal extent, whereas constructs with a monomer of the Bl oligonucleotide in either orientation were inactive (data not shown). The 


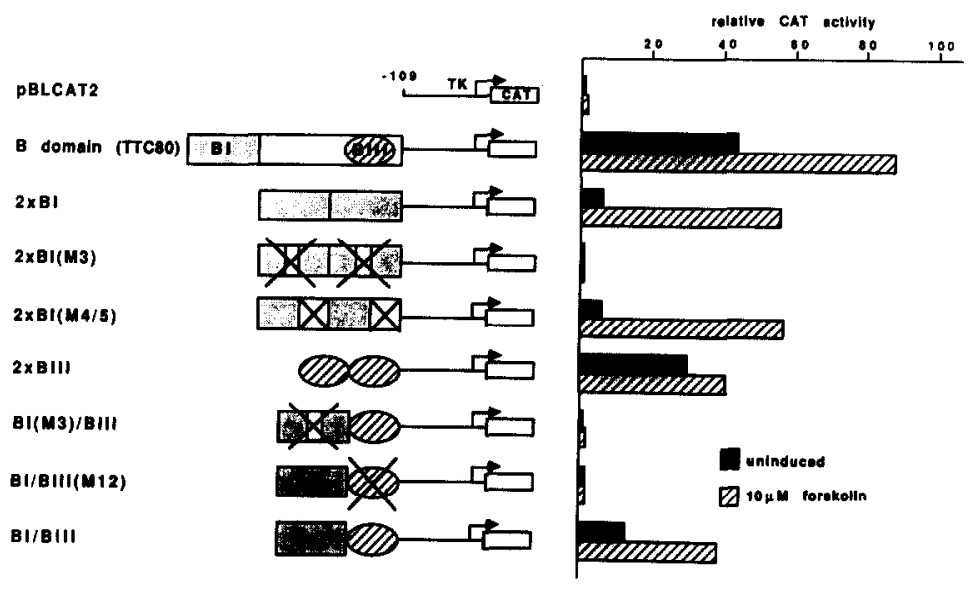

Figure 4. Two Essential Regions of the Enhancer Cooperate and Are Sufficient for Regulated Function

7AD7 (Tse- $1^{-}$) cells were transfected by lipofection (see Experimental Procedures) with the constructs symbolized in the diagram. Nineteen hours after addition of the DNA-lipid complex, cells were split onto duplicate plates, incubated for $3 \mathrm{hr}$ in serum-containing medium to allow attachment to the culture dish, and then induced in serum-free medium with $10 \mu \mathrm{M}$ forskolin or $0.1 \%$ ethanol as solvent control. Cells were harvested after a total expression period of $49 \mathrm{hr}$. CAT activity was determined, corrected for protein, and is given as fold stimulation of the uninduced TK promoter in pBLCAT2, arbitrarily set to 1. The absolute value for uninduced pBLCAT2 is $0.63 \mathrm{pmol} / \mathrm{min}$ per $\mathrm{mg}$.

The sequences of oligonucleotides $\mathrm{BI}$ and BIII are given in Figure 3. BI was synthesized with Xbal and Spel sticky ends (six additional nucleotides) and cloned in sense orientation into the Xbal site of pBLCAT2. BIII was synthesized with BgIII and BamHI sticky ends (three additional nucleotides) and cloned in sense orientation into the BamHI site of pBLCAT2. Mutant versions of the oligonucleotides include the cluster of point mutations given in the bracket (see Figure 3 for mutant sequence). Construct TTC80 includes sequences from -3582 to -3661 and represents the complete $B$ domain.

CRE-like sequence motif was required for inducibility by CAMP as three point mutations in this sequence abolished inducibility (BI(M3) dimer), whereas mutations in adjacent sequences (BI(M4/5) dimer) were neutral. Elsewhere, we have analyzed the mechanism of CAMP-mediated signal transduction to this CRE (F. W., A. F. Stewart, M. B., D. Nitsch, and G. S., submitted). Similarly, a dimer, but not a monomer, of the BIII oligonucleotide (see Figure 3) strongly activated the TK promoter, but was unaffected by forskolin treatment (Figure 4). These findings suggest a strong synergism between a CRE and a constitutive element, both being essential components of the enhancer. The TATCRE has a dual role: it mediates response to CAMP, and in cooperation with the BIII motif, it assures high basal activity of the enhancer. The enhancer activity is only weakly modulated by forskolin induction in 7AD7 (Tse- $1^{-}$) cells. Maximal induction of the transcription rate of the endogenous TAT gene is, however, transient and declines after $60 \mathrm{~min}$ (F. W., A. F. Stewart, M. B., D. Nitsch, and G. S., submitted). Therefore, in transient gene transfer experiments, inducibility of TATCAT constructs becomes apparent only when the basal enhancer activity is repressed by Tse-1.

We have then directly tested synergism between $\mathrm{Bl}$ and BIII by constructing a heterodimer of the two oligonucleotides. As controls and to rule out any effect of spacing or sequence environment, we also constructed mutant versions of this heterodimer in which either of the two motifs was destroyed by the M3 or the M12 cluster of point mutations. As expected, no stimulation of the TK promoter was observed with the mutant versions. The intact BI/BIII heterodimer increased expression about 13-fold and responded to forskolin. The somewhat lower level of activity of the Bl/BIII heterodimer as compared with the intact B domain is in perfect agreement with the analysis of clustered point mutations, which indicates additional weakly mutation-sensitive regions between the two essential motifs (see M4, M5, M6, M8, and M9 in Figure 3).

\section{The Extinguished State of the TAT Gene Is Reflected by Changes in Protein Binding at the CRE}

To analyze the effect of the Tse-1 locus on protein binding in vivo, we have used the genomic footprinting technique. Changes in dimethylsulfate (DMS) reactivity revealing protein-DNA interaction in vivo have been detected at the TATCRE in FTO-2B cells as compared with XC cells (F. W., A. F. Stewart, M. B., D. Nitsch, and G. S., submitted). No difference in DMS reactivity was visible, however, when DNA from XC cells or HTC cells was compared with the naked control (Figure 5A). Thus, specific changes revealing protein binding in vivo at the TATCRE motif mark cells in which the hepatocyte-specific enhancer is functional. The significance of the observed changes is highlighted by the fact that mutation of just the three bases protected from DMS attack completely abolished enhancer activity (construct M3 in Figure 3). No additional changes in DMS reactivity were detected in the entire $B$ domain (data not shown). No changes were observed after induction for 2 $\mathrm{hr}$ with forskolin or dexamethasone as shown in Figure 5A. Glucocorticoids do not affect activity of the hepatocytespecific enhancer but rather act via a separate element at $-2.5 \mathrm{~kb}$ (Jantzen et al., 1987), and forskolin elicits only a transient enhancement of the footprint pattern at the CRE with a peak after $30-50 \mathrm{~min}$ (F. W., A. F. Stewart, M. B., D. Nitsch, and G. S., submitted).

We then asked whether changes in protein binding at the CRE can be detected in the presence of Tse-1. In 7AE27 (Tse- $1^{+}$) cells only a very weak in vivo footprint was seen at the CRE (Figure 5B), compared with the strong footprint in FTO-2B (Tse-1 ${ }^{-}$) cells (Figure $5 \mathrm{~A}$ ). The presence of $T_{s e-1}$ is therefore correlated with loss of footprint activity at the CRE. The full pattern reappeared, however, after induction with forskolin in 7AE27 $\left(\right.$ Tse- $^{+}$) cells (Figure $6 \mathrm{~B}$ ). Thus, protein binding in vivo at the CRE faithfully reflects function of the enhancer: it is active in hepatoma cells, extinguished by $T$ se-1, and reactivated by CAMP in- 


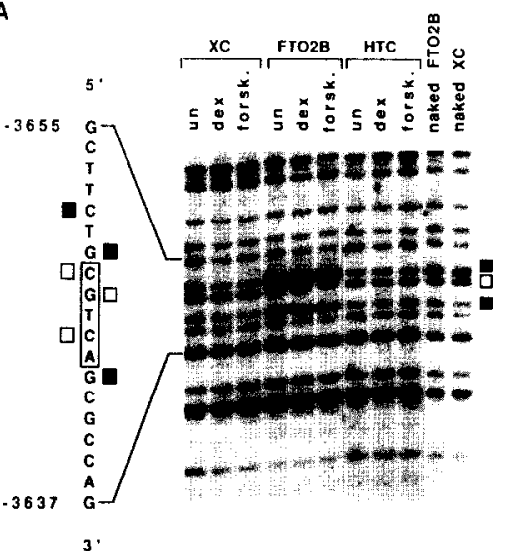

B

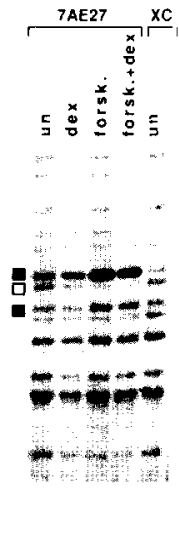

Figure 5. The in Vivo Footprint at the TATCRE is Cell Type Specific and Affected by Tse-1

(A) XC, FTO-2B, and HTC cells were cultured overnight in serum-free medium, then induced for $2 \mathrm{hr}$ with dexamethasone (dex) or with forskolin (forsk.) or treated with $0.1 \%$ ethanol as solvent control (un). After mild trypsinization, cells were reacted with DMS and processed for genomic footprinting as described in Experimental Procedures. Thirty micrograms of Styl-cut genomic DNA per lane was electrophoresed on a $6 \%$ denaturing polyacrylamide gel. For comparison, purified genomic DNA (naked) was reacted in vitro with DMS. After electroblotting and covalent cross-linking to a nylon membrane, hybridization was performed with a single-stranded DNA probe recognizing the sequence from -3516 to -3643 on the upper strand. Guanosine residues from -3619 to -3675 of the upper strand are visible on the autoradiogram. Altered DMS reactivity of guanosine residues is marked with solid squares for enhancements and with open squares for protections. Numbers indicate the positions in base pairs relative to the start site of transcription. The changes on the upper strand, visible on the autoradiogram, are marked to the right of the sequence blowup. Enhancements and protections on the lower strand are marked to the left of the sequence blowup (data not shown). The part of the sequence homologous to the CRE consensus is boxed.

(B) 7AE27 (Tse-1 ${ }^{+}$) and XC cells were processed exactly as described in (A). Guanosine residues from -3619 to -3675 of the upper strand are visible on the autoradiogram.

duction in the Tse-1+ cell line (see Table 2 and Figure 2B). This suggests that changes in protein binding at the CRE are directly involved in negative regulation by $T s e-1$.

\section{The CRE Is the Target for Tse-1}

Consequently, we analyzed the role of the TATCRE in repression by Tse-1. This was complicated by the fact that a dimer of the BI oligonucleotide conferred relatively weak basal activity (see $2 \times \mathrm{Bl}$ in Figure 4 and Table 3). However, a strong synergistic effect was observed when the number of tandemly repeated $\mathrm{Bl}$ oligonucleotides cloned in front of the TK promoter was increased. This led to a drastic increase in basal stimulation with a concomitant decrease in the foldness of induction by forskolin (Figure 6 and data not shown). We made use of this observation for a more sensitive detection of negative regulation and used a pentamer of the Bl oligonucleotide. As control we included a construct with two copies of the SV40 enhancer in front of the TK promoter (pTK14C), which we have shown to be equally expressed in 7AD7 (Tse-1-) and $7 A E 27\left(\right.$ Tse-1 $\left.^{+}\right)$cells and to be unresponsive to forskolin in both cell lines when compared with a variety of different promoters (see Table 2). The results shown in Figure 6 clearly document that the $\mathrm{BI}$ oligonucleotide is responsive to Tse-1. The basal level of expression of construct $5 \times \mathrm{BI}$ was about 20 -fold reduced in 7AE27 $\left(\right.$ Tse-1 $\left.^{+}\right)$, and this effect was fully reversed upon induction with forskolin. Therefore, we conclude that the CRE motif mediates repression by Tse-1. Expression of a pentamer of the BIII oligonucleotide was 3-fold reduced in 7AE27 $\left(\right.$ Tse- $\left.^{+}\right)$cells but was not inducible with forskolin (data not shown). Thus, the CRE is the primary target for repression of the enhancer by Tse-1.

\section{Hepatocyte Specificity of the Enhancer Is Generated by Combinatorial Use of Cell-Specific Elements Fully Dependent on Synergistic Action Knowing that Tse-1 exerts its negative effect via a CRE that is essential for basal activity of a hepatocyte-specific en- hancer, we asked which role this CRE played to determine cell type specificity of the enhancer. To this end, we tested the two elements that are essential and together sufficient for enhancer function (BI and BIII) individually in five different cell lines. As shown in Table 3 the intact B domain}

Table 3. Cell Type-Specific Activity of Elements BI and BIII

\begin{tabular}{|c|c|c|c|c|c|c|c|c|c|c|}
\hline \multirow[b]{3}{*}{ Construct } & \multicolumn{10}{|c|}{ Relative CAT Activity in Extracts from Transfected Cell Lines ${ }^{a}$} \\
\hline & \multicolumn{2}{|c|}{ FTO-2B } & \multicolumn{2}{|c|}{ HTC } & \multicolumn{2}{|l|}{$\mathrm{XC}$} & \multicolumn{2}{|c|}{ HepG2 } & \multicolumn{2}{|c|}{ HeLa } \\
\hline & - & forsk. & - & torsk. & - & forsk. & - & torsk. & - & torsk. \\
\hline pBLCAT2 & 1.0 & 1.9 & 1.0 & 1.1 & 1.0 & 0.9 & 1.0 & 1.0 & 1.0 & 1.3 \\
\hline TTC80 (B domain $)^{\mathrm{b}}$ & 36.0 & 154.0 & 2.2 & 4.8 & 0.8 & 0.8 & 0.9 & 2.0 & 1.3 & 1.4 \\
\hline $2 \times B I^{b}$ & 2.8 & 56.0 & 1.9 & 5.2 & 1.0 & 1.1 & 1.1 & 1.9 & 19.0 & 24.0 \\
\hline $2 \times$ BlI $^{b}$ & 37.0 & 72.0 & 2.4 & 3.2 & 0.5 & 0.5 & 6.5 & 8.2 & 0.6 & 0.6 \\
\hline $\mathrm{BI} / \mathrm{B} \mathrm{II}^{\mathrm{D}}$ & 15.0 & 80.0 & 2.2 & 4.3 & 0.9 & 0.8 & 2.4 & 2.6 & 2.4 & 3.5 \\
\hline $2 \times \operatorname{SOM}^{c}$ & 1.8 & 15.0 & 1.5 & 2.9 & 0.7 & 0.7 & 1.2 & 1.4 & 5.7 & 4.9 \\
\hline SOM/BIIIC & 22.0 & 102.0 & 2.7 & 4.6 & 0.7 & 0.7 & 2.9 & 4.6 & 3.0 & 3.6 \\
\hline
\end{tabular}

a All cell lines were electroporated under identical conditions (see Experimental Procedures) with $10 \mu \mathrm{g}$ of the respective plasmid and $1 \mu \mathrm{g}$ of RSVlucA/H as internal reference. Celis were split onto duplicate plates and kept in medium with $10 \%$ charcoal-stripped serum and were induced with $10 \mu \mathrm{M}$ forskolin (forsk.) or treated with $0.1 \%$ ethanol as solvent control ( - ) directly after electroporation. Extracts were prepared after 50 $\mathrm{hr}$ and assayed for CAT and luciferase activity. CAT values were corrected and are given as relative activity by arbitrarily setting the activity of the uninduced TK promoter in pBLCAT2 to 1 . Absolute values for pBLCAT2 are $1.7 \mathrm{pmol} / \mathrm{min}$ per $\mathrm{mg}$ in FTO-2B, $19 \mathrm{pmol} / \mathrm{min}$ per $\mathrm{mg}$ in HTC, $395 \mathrm{pmol} / \mathrm{min}$ per $\mathrm{mg}$ in XC, $12 \mathrm{pmol} / \mathrm{min}$ per $\mathrm{mg}$ in HepG2, and $10 \mathrm{pmol} / \mathrm{min}$ per $\mathrm{mg}$ in HeLa cells.

b See Figure 4.

c The SOM oligonucleotide encompasses the sequence from -31 to -56 of the rat somatostatin gene (Montminy et al., 1986). 


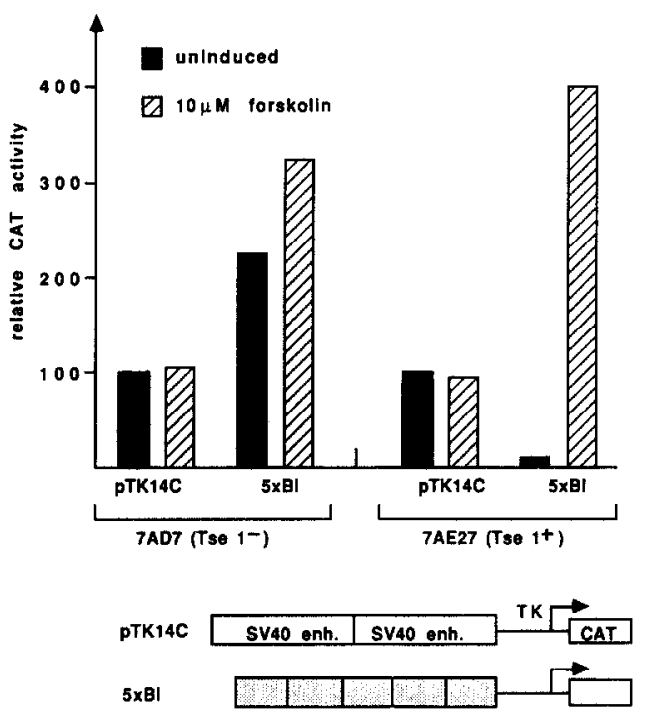

Figure 6. The TATCRE Is Responsive to Tse-1

Duplicate cultures of 7AD7 (Tse- $\left.7^{-}\right)$and 7AE27 $\left(\right.$Tse- $\left.^{+}\right)$cells were transfected by lipofection (see Experimental Procedures) with the constructs depicted in the diagram. Twenty hours after addition of the DNA-lipid complex, medium was changed and incubation was continued under serum-free conditions throughout an expression period of $65 \mathrm{hr}$. Forskolin $(10 \mu \mathrm{M})$ or $0.1 \%$ ethanol was added $22 \mathrm{hr}$ before cells were harvested. CAT activity was corrected for protein and is given as relative activity, arbitrarily setting the value of construct pTK14C to 100 Absolute values for $\mathrm{pTK} 14 \mathrm{C}$ are $64.8 \mathrm{pmol} / \mathrm{min}$ per $\mathrm{mg}$ in $7 \mathrm{AD} 7$ and 67.3 pmol/min per mg in 7AE27 cells. Construct $5 \times \mathrm{BI}$ is exactly analogous to $2 \times B I$ as described in the legend to Figure 4 , but contains five tan dem copies of the Bl oligonucleotide in sense orientation. In construct pTK14C two copies of the SV40 enhancer are placed in front of the TK promoter

(construct TTC80) conferred strong activation onto the TK promoter in FTO-2B cells, but only a minimal effect was seen in HTC cells, and no effect at all was seen in any other cell line tested. This documented that the $B$ domain of the enhancer could confer specificity for highly differentiated hepatoma cells onto a heterologous promoter (compare with Table 1). A dimer of the Bl oligonucleotide was responsive to CAMP in FTO-2B cells, responded weakly in HTC cells, and was inactive in XC or HepG2 cells. However, it was surprising to find a strong constitutive stimulation in HeLa cells. Thus, the CRE motif alone cannot fully account for restriction of enhancer activity to FTO-2B cells. A dimer of the somatostatin (SOM) CRE paralleled the activity of the TATCRE in the different cell lines. The second essential component of the enhancer (BIII motif) is apparently hepatoma specific: it is inactive in XC and HeLa cells, strongly active in well-differentiated rat hepatoma cells (FTO-2B), moderately active in HepG2, and very weakly active in HTC cells. As expected, strong activity of the BI/BIII heterodimer or a SOM/BIII heterodimer was only observed in FTO-2B cells where both essential elements are fully functional. Thus, the basic principle tightly restricting activity of the enhancer to well-differentiated rat hepatoma cells seems to involve combinatorial use of elements with distinct cell type specificity that are functionally interdependent.

\section{Discussion}

The experiments reported here document a triple role for a CRE: first, it is essential for function of a liver-specific enhancer; second, it mediates negative regulation of this enhancer by Tse-1; and third, it responds to CAMP induction in $\mathrm{Tse}-\mathrm{T}^{+}$cells, thereby reverting repression by Tse-1. Thus, the functional antagonism between Tse-1 and the cAMP pathway in monochromosomal hybrids (Thayer and Fournier, 1989; Ruppert et al., 1990) is reflected by a colocalization of sequences mediating CAMP and Tse- 1 response.

How Does Tse-1 Affect Protein Binding at the CRE? Several mechanisms of action can be envisaged that result in repression of the TATCRE, accompanied by changes in protein binding at this site. Tse-1 might either modulate the DNA binding affinity or intracellular localization of a TATCRE binding protein or regulate its abundance. Alternatively, Tse-1 might be a repressor competing for binding with a TATCRE binding factor.

By genomic footprinting we have observed that in the cell line 7AE27 (Tse-1 ${ }^{+}$), footprint activity at the TATCRE increases after CAMP induction, even if protein synthesis is completely blocked by cycloheximide (data not shown). Thus, a posttranslational event seems to contribute to the switch from the extinguished to the expressing state. Cotransfection of an expression vector encoding the catalytic subunit of protein kinase $A$ is sufficient to overcome repression of TATCRE function by Tse-1 in 7AE27 (Tse-1+) cells (A. S. and M. B., unpublished data). This was expected as protein kinase $A$ mediates intracellular CAMP effects (for review see Edelman et al., 1987). Thus, it is very tempting to speculate that Tse-1 might change the phosphorylation state of a protein important for TATCRE function, for example, via a specific phosphatase activity. We detected a TATCRE binding activity in hepatoma nuclear extracts that increased upon cAMP induction (F. W., A. F. Stewart, M. B., D. Nitsch, and G. S., submitted). As binding activity of CRE binding protein (Hoeffler et al., 1988; Gonzalez et al., 1989) is not enhanced by kinase A-mediated activation (Yamamoto et al., 1988), the TAT. CRE binding activity might be a distinct member of the CRE binding protein/ATF family of transcription factors (Hai et al., 1989; Maekawa et al., 1989; for reviews see Karin, 1989; Mitchell and Tjian, 1989). Other possible mechanisms of Tse-1 action might involve sequestration of a TATCRE binding protein as described for NF- $\mathrm{BB}$ (Baeuerle et al., 1988). Analysis of the state of phosphorylation of the TATCRE binding protein in extinguished $\left(\mathrm{Tse}^{+} \mathrm{-}^{+}\right)$cells or its possible association with an inhibitory subunit in these cells may allow elucidation of the mode of action of Tse-1.

Down-regulation of the mRNA encoding the cell typespecific transcription factor GHF1, which is essential for growth hormone gene transcription, has been found in somatic cell hybrids between pituitary cells and fibroblasts, where expression of the growth hormone gene is extinguished (McCormick et al., 1988). Immunoglobulin heavy and $\kappa$ light chain gene promoters and the heavy chain enhancer are targets for extinction in myeloma $\times$ fibroblast 
somatic cell hybrids (Junker et al., 1988), and this is accompanied by down-regulation of the mRNA coding for the lymphoid-specific transcription factor Oct-2 (OTF-2) (Bergman et al., 1990; P. Matthias and S. Junker, personal communication). Thus, in these two systems fibroblast factors suppress synthesis of transcription factors critical for cell type-specific gene transcription. However, in contrast to Tse-1, these fibroblast factors have not yet been defined by genetic analysis, and extinction in whole cell hybrids might well be the result of several factors acting via distinct mechanisms. Evidence for additional mechanisms involved in extinction of the growth hormone gene (Triputti et al., 1988) and the immunoglobulin heavy chain gene (Zaller et al., 1988; Yu et al., 1989) has been reported.

Two observations argue against the possibility that Tse-1 itself binds at the TATCRE site and represses by displacing a transcription factor required for function. First, genomic footprinting indicates loss of protein binding at the TATCRE in the extinguished state. Second, none of our clustered point mutations selectively affects repression.

\section{Double Control of Cell Type-Specific Enhancer Activity}

The hepatocyte-specific enhancer described in this report provides a clear paradigm for mechanisms that guarantee a high degree of cell type specificity of transcriptional control. We defined two distinct sequence motifs absolutely essential for function of this enhancer. Both motifs are inactive on their own but stimulate transcription of a heterologous promoter upon multimerization. When both motifs are linked, they act synergistically, and an element is generated with all regulatory characteristics of the enhancer at $-3.6 \mathrm{~kb}$. As a consequence of this functional interdependence, the enhancer works only in cells where both elements are active. This is only the case in highly differentiated rat hepatoma cells (FTO-2B and 7AD7). The parallel behavior of the TATCRE and the SOMCRE in different cell lines suggests that the functional state of the CAMP signal transduction pathway is important for cell type-specific expression of the TAT gene. In other words, Tse-1 might elicit gene- and cell-specific effects by interfering with a signal transduction pathway shared by many different cell types. Constitutive activation of the cAMP pathway in HeLa cells was noted previously (Iguchi-Ariga and Schaffner, 1989)

Since recognition of the modular structure of enhancers and promoters, it has been suggested that modularity might be an economical mechanism to create a large number of regulatory patterns by combinatorial use of a smaller number of regulatory proteins (Serfling et al., 1985; Dynan, 1989). Here, we provide a particularly clear example to support this concept. The observation of coordinate control of overlapping sets of liver genes by two trans-acting loci (see Ruppert et al., 1990) provides genetic evidence for the same concept. Probably, in most nonliver cells Tse- 1 leads to repression of basal activity of the TATCRE, and at the same time the hepatoma-specific BIII motif is inactive. This leads to two levels of control of cell type-specific enhancer activity. Therefore, the modu- lar structure provides not only an economical but also a very restrictive mechanism for cell type-specific transcriptional control.

\section{Developmental Regulation of TAT Gene Transcription}

Expression of TAT first rises around birth, but can be prematurely activated by administration of CAMP in utero (see Introduction). Tse-1 activity is expressed in mouse hepatoma cells with a fetal liver phenotype (Peterson and Fournier, 1989), but is absent in highly differentiated hepatoma cells expressing adult hepatic markers. As Tse-1 and CAMP both act via a CRE, these observations suggest a model for regulation of the timed onset of expression based on the antagonism between Tse- 1 and the CAMP pathway. As the balance between activity of Tse-1 and the CAMP pathway is critical for function of the TATCRE and as this element has to cooperate with a second essential element (BIII), the enhancer can work as a sensitive switch responding to changes in the Tse-1/cAMP balance with dramatic changes in overall activity. Thus, decrease of Tse-1 activity during liver development would render the repressed TAT gene increasingly responsive to hormonal stimulation toward the end of gestation. The timed onset of TAT expression around birth would then be triggered by the strong release of gluconeogenic hormones acting via the cAMP pathway, resulting from neonatal hypoglycemia. In the accompanying paper we provide genetic evidence that $T$ se- 1 coordinately regulates a set of liverspecific genes that are all inducible via the cAMP pathway (Ruppert et al., 1990). We anticipate that the genes share regulatory elements with similar properties. We are now testing whether a Tse-1 response element can specify the timed onset of expression in transgenic mice. If this concept were correct, monochromosomal hybrids would represent a cell culture model to study a developmental activation process triggered by hormones.

\section{Experimental Procedures}

Plasmid Constructions

All constructs encompassing the rat TAT promoter are based on the plasmid TATCAT $-2950 /+62$, which is described in Jantzen et al. (1987). TATCAT $-4289 /+62$ was generated by inserting further upstream sequences from a phage clone (see D. Nitsch, A. F. Stewart, M. B., R. Mestril, F. W., and G. S., submitted). The endpoints of $5^{\prime}$ and $3^{\prime}$ internal deletions (see Figure 2A) all correspond to restriction sites in the TAT sequence that were used for construction (details available upon request). The sequence of the TAT upstream region will be filed to the EMBL data bank. The set of clustered point mutations was generated by the oligonucleotide cassette technique (Grundström et al., 1985). A 131 bp Sphi-Xbal fragment was assembled from 14 oligonucleotides and ligated directly into TATCAT $-4289 /+62$ via naturally occurring restriction sites (Sphl at -3675 and Xbal at -3544 ). Thus, the cluster of mutations is the only sequence change in the entire construct. Details of the procedure will be published elsewhere.

Constructs with the TK promoter are based on the vector PBLCAT2 (Luckow and Schütz, 1987). The TTC series (see Figure 2B) was constructed by inserting various restriction fragments from the enhancer region in sense orientation into the polylinker of pBLCAT2 (details available upon request). To generate $2 \times \mathrm{BI}, 5 \times \mathrm{BI}$, and $2 \times$ SOM the following complementary oligonucleotides were synthesized, gel-purified, head-to-tail tandemerized via the cohesive Xbal and Spel ends, and cloned in sense orientation into the Xbal site of PBLCAT2. 
Bl oligonucleotide:

CTAGATGCAGCTTCTGCGTCAGCGCCAGTATA TACGTCGAAGACGCAGTCGCGGTCATATGATC

SOM oligonucleotide

C TAGA ICCTTGGCTGACGTCAGAGAGAGAGTA

TAGGAACCGACTGCAGTCTCTCTCTCATGATC

In the same way $2 \times$ BIII and $5 \times$ Blll were generated from the following complementary oligonucleotides, which have Bglll and BamHI cohesive ends and were cloned into the BamHI site of pBLCAT2:

BIIl oligonucleotide:

$$
\begin{aligned}
\text { GATCTGCTGCTCTTTGATCTG } \\
\text { ACGACGAGAAACTAGACCTAG }
\end{aligned}
$$

Construct $\mathrm{BI} / \mathrm{BIII}$ has one copy of the $\mathrm{Bl}$ oligonucleotide in the $\mathrm{Xbal}$ site and one copy of the BIII oligonucleotide in the BamHI site, both in sense orientation. SOM/BIII was constructed analogously. For mutant versions of these constructs, oligonucleotides with the M3, M4/5, or M12 cluster of point mutations (see Figure 3), but otherwise identical were used. Standard cloning procedures are described in Ausubel et al. (1988). All constructions were verified by plasmid sequencing (Chen and Seeburg, 1985) using $T 7$ polymerase and the Sequenase ${ }^{T M}$ protocol (US Biochemical). Plasmids were grown in Escherichia coli $\mathrm{HB} 101$ and purified by alkaline lysis and two successive $\mathrm{CsCl}$ gradients, followed by dialysis and ethanol precipitation.

\section{Cell Culture and Transfections}

The rat hepatoma lines FTO-2B, 7AD7, and 7AE27 are described in Killary and Fournier (1984) and Leach et al. (1989). Frozen stocks from subclones of these lines were prepared, and all experiments were done with aliquots from the same stock, freshly thawed every 4-6 weeks. Hepatoma 'cells were cultured in a 1:1 (vol/vol) dilution of Dulbeccos's modified Eagle's medium (DMEM) and Ham's F12 medium. For XC and HeLa cells DMEM was used. Media were supplemented with $10 \%$ fetal calf serum, $100 \mathrm{U} / \mathrm{ml}$ penicillin, $100 \mu \mathrm{g} / \mathrm{ml}$ streptomycin, $10 \mathrm{mM}$ HEPES ( $\mathrm{pH} 7.4$ ), and $2 \mathrm{mM}$ glutamine. The medium for 7AD7

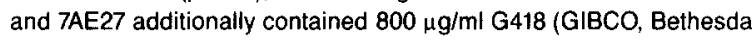
Research Laboratories). Cells were grown at $37^{\circ} \mathrm{C}$ in $5 \% \mathrm{CO}_{2}$

Electroporation (Fromm et al., 1985; Chu et al., 1987) was performed with the Gene Pulser ${ }^{T M}$ and Capacitance Extender ${ }^{T M}$ from Bio-Rad. Cells were trypsinized, washed with $\mathrm{Ca}^{2+}$ - and $\mathrm{Mg}^{2+}$-free phosphatebuffered saline and resuspended in phosphate-buffered saline at a concentration of $2 \times 10^{7}$ cells/ml (FTO-2B, HepG2, and HeLa) or $1 \times$ $10^{7}$ cells $/ \mathrm{ml}$ (XC and HTC). Five hundred milliters of the suspension was mixed with $10 \mu \mathrm{g}$ of plasmid DNA plus $1 \mu \mathrm{g}$ of the reference plasmid RSVlucA/H. In this construct, provided by A. Hecht, the firefly luciferase gene (de Wet et al., 1987) is driven by the RSV promoter and enhancer. Cells were pulsed immediately after transfer to electroporation cuvettes (Bio-Rad) at room temperature with $960 \mu \mathrm{F}$ and $250 \mathrm{~V}$. After 5-10 min the cells were diluted in medium containing charcoalstripped fetal calf serum and plated.

For lipofection (Felgner et al., 1987) $2 \times 10^{6}$ to $4 \times 10^{6}$ cells were plated onto $60 \mathrm{~mm}$ dishes 1 day before transfection. Both $0.5 \mathrm{pmol}$ of plasmid DNA and $33 \mu \mathrm{g}$ of the Lipofectin ${ }^{T M}$ reagent (provided by G. Ringold or purchased from GIBCO, Bethesda Research Laboratories) were diluted separately in $500 \mu$ l of HBS buffer $(20 \mathrm{mM} \mathrm{HEPES} \mathrm{[pH}$ 7.4], $150 \mathrm{mM} \mathrm{NaCl}$ ). Where indicated, 0.05 pmot of the referemce plasmid RSVlucA/H was included. The DNA and Lipofectin ${ }^{\mathrm{TM}}$ dilutions were mixed at room temperature and 10-15 min later added to the cells, previously washed twice with serum-free medium. After a $3 \mathrm{hr}$ incubation at $37^{\circ} \mathrm{C}$ with the DNA/Lipofectin ${ }^{\top M} \mathrm{mix}, 2 \mathrm{ml}$ of serum-free medium was added, and incubation was continued overnight (12-16 hr). Medium was then replaced or cells were split for inductions.

\section{CAT and Luciferase Assays}

Cells were washed twice with phosphate-buffered saline, harvested in

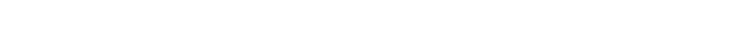
by low speed centrifugation. Extracts were prepared in $300 \mu \mathrm{l}$ of 250 $\mathrm{mM}$ Tris (pH 7.8), $1 \mathrm{mM}$ EDTA, $1 \mathrm{mM}$ dithiothreitol, $0.2 \%$ Saponin by 3 cycles of freezing and thawing and were cleared by centrifugation at $10,000 \times \mathrm{g}$, at $4^{\circ} \mathrm{C}$ for $20 \mathrm{~min}$. The protein concentration was determined by the Bradford assay (Bradford, 1976). CAT assays were per- formed at $37^{\circ} \mathrm{C}$ in a total volume of $200 \mu$ with $250 \mathrm{mM}$ Tris $(\mathrm{pH} \mathrm{7.8)}$, $5 \mathrm{mM}$ EDTA. $2 \mathrm{mM}$ acetyl coenzyme A (Pharmacia), and $1.25 \mu \mathrm{Ci} / \mathrm{ml}$ ${ }^{14} \mathrm{C}$ chloramphenicol (New England Nuclear) final concentrations. Extracts were heat treated $\left(10 \mathrm{~min}, 60^{\circ} \mathrm{C}\right)$ to inactivate deacetylase activity (Crabb and Dixon, 1987). Under these conditions the assay was linear up to several hours and up to $100 \mu \mathrm{l}(\sim 1 \mathrm{mg})$ of extract. Routinely, the assay was run for $1-2 \mathrm{hr}$ with the amount of extract required to convert $0.5 \%-50 \%$ of the substrate to the acetylated form. Assays outside this range were repeated using the appropriate amount of extract or a different reaction time. After thin-layer chromatography the unacetylated chloramphenicol and the acetylated forms were quantified by liquid scintillation counting to determine the conversion rate. The activity is expressed as picomoles of acetylated chloramphenicol per minute per milligram of extract protein or as relative activity. Luciferase activity was measured in $50 \mu$ lof the freshly prepared extract as described in de Wet et al. (1987).

\section{RNA Start Site Mapping}

Total RNA was extracted by the guanidinium isothiocyanate/ $\mathrm{CsCl}$ cushion method (Chirgwin et al., 1979). TATCAT-specific mRNA was quantitated, and transcription start sites were determined with a ribonuclease protection assay (Melton et al., 1984) using a uniformly labeled probe spanning positions -108 to +216 of TATCAT (Jantzen el al., 1987). One hundred micrograms of RNA was hybridized to 10 fmol $\left(1.6 \times 10^{6} \mathrm{dpm}\right)$ of gel-purified probe, digested at $30^{\circ} \mathrm{C}$ for $1 \mathrm{hr}$ with $10 \mu \mathrm{g} / \mathrm{ml}$ RNAase $A$ and $100 \mathrm{U} / \mathrm{ml}$ RNAase T1.

\section{Genomic Footprinting}

Cells $\left(0.5 \times 10^{8}\right.$ to $\left.1 \times 10^{8}\right)$ were collected by mild trypsinization and resuspended in $1 \mathrm{ml}$ of serum-free medium before addition of DMS. All subsequent steps were performed according to Becker and Schütz (1988), except that presaturation of vector-specific sequences with sheared single-stranded vector DNA prior to hybridization was unnecessary, as a cDNA probe of high specific activity was synthesized from an RNA template as described (Weih et al., 1988). The probe used (HS127) recognized positions -3516 (Styl) to -3643 (Hhal).

\section{Acknowledgments}

We wish to thank $A$. J. Leach for generously providing us with the cell lines 7AD7 and 7AE27. We also thank $S$. Cereghini for the albumin CAT construct, E. De Simone for the $\alpha_{1}$-antitrypsin CAT construct, and A. Hecht for RSVlucA/H. Free samples of Lipofectin ${ }^{T M}$ reagent were a kind gift of G. Ringold. J. Holm and M. Klüppel contributed to this work during an undergraduate laboratory course. We gratefully acknowiedge $E$. Schmid and A. F. Stewart for subcioning of the cell lines 7AD7 and 7AE27, W. Fleischer for synthesis of oligonucleotides, S. Mähler for artwork, and $\mathrm{C}$. Schneider for excellent secretarial assistance. We thank R. Heilbronn, P. Jansen-Duerr, G. Kelsey, D. Nitsch, S. Ruppert, W. Schmid, A. F. Stewart, and U. Strähle for stimulating discussions and critical reading of the manuscript. This work was supported by a grant from the Deutsche Forschungsgemeinschaft (Leibniz-Programm).

The costs of publication of this article were defrayed in part by the payment of page charges. This article must therefore be hereby marked "advertisement" in accordance with 18 U.S.C. Section 1734 solely to indicate this fact.

Received December 19, 1989; revised March 5, 1990

\section{References}

Ausubel, F. M., Brent, R., Kingston, R. E., Moore, D. D., Seidman, J. G., Smith, J. A., and Struhl, K. (1988). Current Protocols in Molecular Biology (New York: Greene/Wiley-Interscience).

Baeuerle, P. A., and Baltimore, D. (1988). IאB: a specific inhibitor of the $N F-\kappa B$ transcription factor. Science $242,540-546$.

Becker, P. B., and Schütz, G. (1988). Genomic footprinting. In Genetic Engineering, Principles and Methods, Vol. 10, J. K. Setlow, ed. (New York: Plenum Press), pp. 1-19.

Bergman, Y., Strich, B., Sharir, H., Ber, R., and Laskov, R. (1990). Extinction of Ig genes expression in myeloma $\times$ fibroblast somatic cell hybrids is accompanied by repression of the oct-2 gene encoding a B-cell specific transcription factor. EMBO J. 9, 849-855. 
Blau, H. M., Pavlath, G. K., Hardeman, E. C., Chiu, C. P., Silberstein, L., Webster. S. G. Miller, S. C., and Webster, C. (1985). Plasticity of the differentiated state. Science 230, 758-766.

Bradford, M. (1976). A rapid and sensitive method for the quantitation of microgram quantities of protein utilizing the principle of protein-dye binding Anal. Biochem. 72, 248-254.

Brown, J. E., and Weiss, M. C. (1975). Activation of production of mouse liver enzymes in rat hepatoma-mouse lymphoid cell hybrids. Cell 6, 481-494

Chen, E. Y., and Seeburg, P. H. (1985). Supercoil sequencing: a fast and simple method for sequencing plasmid DNA. DNA 4, 165-170.

Chin, A. C., and Fournier, R. E. K. (1987). A genetic analysis of extinction: trans-regulation of 16 liver-specific genes in hepatoma-fibroblast hybrid cells. Proc. Natl. Acad. Sci. USA 84, 1614-1618.

Chin, A. C., and Fournier, R. E. K. (1989). Tse-2: a trans-dominant extinguisher of albumin gene expression in hepatoma hybrid cells. Mol. Cell. Biol. 9. 3736-3743.

Chirgwin, J. M., Przybyla, A. E., MacDonald, R. J., and Rutter, W. J. (1979). Isolation of biologically active ribonucleic acid from sources enriched in ribonuclease. Biochemistry $18,5294-5299$

Chu, G., Hoyakawa, H., and Berg, P. (1987). Electroporation for the efficient transfection of mammalian cells with DNA. Nucl. Acids Res. 15 1311-1326.

Ciliberto, G., Dente, L., and Cortese, R. (1985). Cell-specific expression of a transfected human $\alpha_{1}$-antitrypsin gene. Cell $41,531-540$.

Comb. M. Birnberg, N. C., Seasholtz, A., Herbert, E., and Goodman, H. M. (1986). A cyclic AMP- and phorbol ester-inducible DNA element. Nature 323, 353-356.

Crabb, D. W., and Dixon, J. E. (1987). A method for increasing the sensitivity of chloramphenicol acetyltransferase assays in extracts of transfected cultured cells. Anal. Biochem. 163, 88-92.

Davidson, R. L. (1974). Gene expression in somatic cell hybrids. Annu. Rev. Genet. 8, 195-218.

Davidson, R. L., Ephrussi, B., and Yamamoto, K. (1966). Regulation of pigment synthesis in mammalian cells as studied by somatic hybridisation. Proc. Natl. Acad. Sci. USA 56, 1437-1440.

Davis, F. M., and Adelberg, E. A. (1973). Use of somatic cell hybrids for analysis of the differentiated state. Bacteriol. Rev. 37, 197-214.

Delegeane, A. M., Ferland, L. H., and Mellon, P. L. (1987). Tissue specific enhancer of the human glycoprotein hormone $\alpha$-subunit gene: de pendence on cyclic AMP-inducible elements. Mol. Cell. Biol. 7, 39944002

de Wet, J. R., Wood, K. V., DeLuca, M., Helinski, D. R., and Subramani, S. (1987). Firefly luciferase gene: structure and expression in mammalian cells. Mol. Cell. Biol. 7, 725-737.

Dynan, W. S. (1989). Modularity in promoters and enhancers. Cell 58 , $1-4$

Edelman, A. M., Blumenthal, D. K., and Krebs, E. G. (1987). Protein serine/threonine kinases. Annu. Rev. Biochem. 56, 567-613.

Felgner, P. L., Gadek, T. R., Holm, M., Roman, R., Chan, H. W., Wenz, M., Northrop, J. P., Ringold, G. M., and Danielsen, M. (1987). Lipofection: a highly efficient, lipid-mediated DNA-transfection procedure Proc. Natl. Acad. Sci. USA 84, 7413-7417.

Fisch, T. M., Prywes, R., Simon, M. C., and Roeder, R. G. (1989). Multiple sequence elements in the $c$-fos promoter mediate induction by cAMP. Genes Dev. 3, 198-211.

Fromm, M., Taylor, L. P., and Walbot, V. (1985). Expression of genes transferred into monocot and dicot plant cells by electroporation. Proc Natl. Acad. Sci. USA 82, 5824-582.

Ghisalberti, A. V., Steele, J. G., Cake, M. H., McGrath, M. C., and Oliver, I. T. (1980). Role of adrenalin and cyclic AMP in appearance of tyrosine aminotransferase in perinatal rat liver. Biochem. J. 190, 685-690.

Gonzalez, G., Yamamoto, K. K., Fischer, W. H., Karr, D., Menzel, P., Biggs, W., III, Vale, W. W., and Muntminy, M. R. (1989). A cluster of phosphorylation sites on the cyclic AMP-regulated nuclear factor CREB predicted by its sequence. Nature 337, 749-752.

Gorman, C. M., Moffat, L. F., and Howard, B. H. (1982). Recombinant genomes which express chloramphenicol acetyltransferase in mam. malian cells. Mol. Cell. Biol. 2, 1044-1051

Gourdeau, H., Peterson, T. C., and Fournier, R. E. K. (1989). Differential activity of a tissue-specific extinguisher locus in hepatic and nonhepatic cells. Mol. Cell. Biol. 9, 1813-1822.

Granner, D. K., and Beale, E. G. (1985). Regulation of the synthesis of tyrosine aminotransferase and phosphoenolpyruvate carboxykinase by glucocorticoid hormones. In Biochemical Actions of Hormones XII, G. Litwack, ed. (New York: Academic Press), pp. 89-138.

Greengard, $O .(1970)$. The developmental formation of enzymes in rat liver. In Mechanism of Hormone Action I, G. Litwack, ed. (New York: Academic Press), pp. 53-85.

Grundström, T., Zenke, W. M., Wintzerith, M., Matthes, H. W. D., Staub, A., and Chambon, P. (1985). Oligonucleotide-directed mutagenesis by microscale "shot-gun" gene synthesis. Nucl. Acids Res. 9, 3305-3316. Hai, T., Liu, F., Coukos, W. J., and Green, M. R. (1989). Transcription factor ATF CDNA clones: an extensive family of leucine zipper proteins able to selectively form DNA-binding heterodimers. Genes Dev. 3 , 2083-2090.

Hargrove, J. L., and Granner, D. K. (1985). Biosynthesis and intracellular processing of tyrosine aminotransferase. In Transaminases, $P$. Christen and P. E. Metzler, eds. (New York: John Wiley \& Sons, Inc.), pp. 511-532.

Hashimoto, S., Schmid, W., and Schütz, G. (1984). Transcriptional activation of the rat liver tyrosine aminotransferase gene by CAMP. Proc. Natl. Acad. Sci. USA 81, 6637-6641.

Heard, J.-M., Herbomel, P., Ott, M.-O., Mottura-Rolter, A., Weiss, M. C. and Yaniv, M. (1987). Determinants of rat albumin promoter tissue specificity analysed by an improved transient expression system. Mol. Cell. Biol. 7, 2425-2434.

Hoeffler, J. P., Meyer, T. E., Yun, Y., Jameson, J. L., and Habener, F. (1988). Cyclic AMP-responsive DNA-binding protein: structure based on a cloned placental CDNA. Science 242, 1430-1433.

Iguchi-Ariga, S. M. M., and Schaffner, W. (1989). CpG methylation of the cAMP-responsive enhancer/promoter sequence TGACGTCA abolishes specific factor binding as well as transcriptional activation. Genes Dev. 3, 612-619.

Jantzen, H.-M., Strähle, U., Gloss, B., Stewart, F., Schmid, W., Boshart, M., Miksicek, R., and Schütz, G. (1987). Cooperativity of glucocorticoid response elements located far upstream of the tyrosine aminotransferase gene. Cell 49, 29-38.

Junker, S., Nielsen, V., Matthias, P., and Picard, D. (1988). Both immunoglobulin promoter and enhancer sequences are targets for suppression in myeloma-fibroblast hybrid cells. EMBO J. 7, 3093-3098.

Karin, M. (1989). Complexities of gene regulation by cAMP. Trends Genet. 5, 65-67.

Killary, A. M., and Fournier, R. E. K. (1984) A genetic analysis of extinction: trans-dominant loci regulate expression of liver-specific traits in hepatoma hybrid cells. Cell 38, 523-534

Killary, A. M., Lugo, T. G., and Fournier, R. E. K. (1984). Isolation of thymidine kinase deficient rat hepatoma cells by selection with bromodeoxyuridine, Hoechst 33258 and visible light Biochem. Genet. 22. 201-213.

Knowles, B. B., Howe, C. C., and Aden, D. P. (1980). Human hepatocellular carcinoma cell lines secrete the major plasma proteins and hepatitis B surface antigen. Science 209, 497-499.

Leach, R. J., Thayer, M. J., Schafer, A. J., and Fournier, R. F. K. (1989). Physical mapping of human chromosome 17 using fragment-containing microcell hybrids. Genomics 5, 167-176.

Lem, J., Chın, A. C., Thayer, M. J., Leach, R. J., and Fournier, R. E. K. (1988). Coordinate regulation of two genes encoding gluconeogenic enzymes by the trans-dominant locus Tse-1. Proc. Natl. Acad. Sci. USA $85,7302-7306$

Luckow, B., and Schütz, G. (1987). CAT constructions with multiple unique restriction sites for the functional analysis of eukaryotic promoters and regulatory elements. Nucl. Acids Res. 15, 5490

Maekawa, T., Sakura, H., Kanei-Ishii, C., Sudo, T., Yoshimura, T. Fujisawa, J., Yoshida, M., and Ishii, S. (1989). Leucine zipper structure 
of the protein CRE-BP1 binding to the cyclic AMP response element in brain. EMBO J. 8, 2023-2028.

McCormick, A., Wu, D., Castrillo, J.-L., Dana, S., Strobl, J., Thompson, E. B., and Karin, M. (1988). Extinction of growth hormone expression in somatic cell hybrids involves repression of the specific transactivator GHF-1. Cell 55, 379-389.

Melton, D. A., Krieg, P. A., Rebagliati, M. R., Maniatis, T., Zinn, K., and Green, M. R. (1984). Efficient in vitro synthesis of biologically active RNA and RNA-hybridisation probes from plasmids containing a bacteriophage SP6 promoter. Nucl. Acids Res. 12, 7035.7056.

Mevel-Ninio, M., and Weiss, M. C. (1981). Immunofluorescence analysis of the time-course of extinction, reexpression, and activation of albumin production in rat hepatoma-fibroblast heterokaryons and hybrids. J. Cell Biol. 90, 339-350.

Mitchell, P. J., and Tjian, R. (1989). Transcriptional regulation in mammalian cells by sequence-specific DNA binding proteins. Science 245 , 371-378.

Montminy, M. R., Sevarino, K. A., Wagner, J. A., Mandel, G., and Goodman, R. H. (1986). Identification of a cyclic-AMP responsive element within the rat somatostatin gene. Proc. Natl. Acad. Sci. USA 83, 6682-6686.

Müller, G., Scherer, G., Zentgraf, H., Ruppert, S., Herrmann, B., Lehrach, H., and Schütz, G. (1985). Isolation, characterisation and chromosomal mapping of the mouse tyrosine aminotransferase gene. J. Mol. Biol. 184, 367-373.

Peterson, J. A., and Weiss, M. C. (1972). Expression of differentiated functions in hepatoma cell hybrids: induction of mouse albumin production in rat hepatoma-mouse fibroblast hybrids. Proc. Natl. Acad. Sci. USA $69,571-575$.

Peterson, T. C., and Fournier, R. E. K. (1989). Genetic activity of a trans regulatory locus in hepatoma hybrid cells. Mol. Biol. Med. 6, 109-116. Peterson, T. C., Killary, A. M., and Fournier, R. E. K. (1985). Chromosomal assignment and trans-regulation of the tyrosine aminotransferase structural gene in hepatoma hybrid cells. Mol. Cell. Biol. 5. 2491-2494

Petit, C., Levilliers, J., Ott, M. O., and Weiss, M. C. (1986). Tissuespecific expression of the rat albumin gene: genetic contol of its extinction in microcell hybrids. Proc. Natl. Acad. Sci. USA 83, 2561-2565. Quinn, P. G., Wong, T. W., Magnuson, M. A., Shabb, J. B., and Granner, D. K. (1988). Identification of basal and cyclic AMP regulatory elements in the promoter of the phosphoenolpyruvate carboxykinase gene. Mol. Cell. Biol. 8, 3467-3475.

Ruiz-Bravo, N., and Ernest, M. J. (1982). Induction of tyrosine aminoIransferase mRNA by glucocorticoids and CAMP in fetal rat liver. Proc.

Ruppert, S., Boshart, M., Bosch, F. X., Schmid, W., Fournier, R. E. K. and Schütz, G. (1990). Two genetically defined trans-acting loci coordinately regulate overlapping sets of liver-specific genes. Cell 61 , this issue.

Schmid, E., Schmid, W., Mayer, D., Jastorff, B., and Schütz, G. (1987). Transcriptional activation of the tyrosine aminotransferase gene by glucocorticoids and CAMP in primary hepatocytes. Eur. J. Biochem. 165, 499-506.

Schneider, J. A., and Weiss, M. C. (1971). Expression of differentiated functions in hepatoma cell hybrids. I. Tyrosine aminotransferase in hepatoma-fibroblast hybrids. Proc. Natl. Acad. Sci. USA 68, 127-131. Seamon, K. B., Padgett, W., and Daly. J. W. (1981). Forskolin: unique diterpene activator of adenylate cyclase in membranes and in intact cells. Proc. Natl. Acad. Sci. USA 78, 3363-3367.

Serfling, E., Jasin, M., and Schaffner, W. (1985). Enhancers and eucaryotic gene transcription. Trends Genet. 1, 224-230.

Shaul, Y., and Ben-Levy, R. (1987). Multiple nuclear pioteins in liver cells are bound to hepatitis $B$ virus enhancer element and its upstream sequences. EMBO J. 6, 1913-1920.

Silver, B. J., Bokar, J. A., Virgin, J. B., Vallen, E. A., Milsted, A, and Nilson, J. H. (1987). Cyclic AMP regulation of the human glycoprotein hormone $\alpha$-subunit gene is mediated by an 18-base-pair element. Proc. Natl.Acad Sci UISA 84 2198-2202
Sparkes, R. S., and Weiss, M. C. (1973). Expression of differentiated functions in hepatoma cell hybrids: alanine aminotransferase. Proc. Natl. Acad. Sci. USA 70, 377-381.

Svoboda, J. (1960). Presence of chicken tumor virus in the sarcoma of the aduit rat inoculated after birth with Rous sarcoma virus. Nature 186, 980-981.

Thayer, M. J., and Fournier, R. E. K. (1989). Hormonal regulation of Tse1-repressed genes: evidence for multiple genetic controls in extinction. Mol. Cell. Biol. 9, 2837-2846.

Thompson, E. B., Tomkins, G. M., and Curran, J. F. (1966). Induction of tyrosine $\alpha$-ketoglutarat transaminase by steroid hormones in a newly established tissue culture cell line. Proc. Natl. Acad. Sci. USA 56, 296-303.

Triputti, P., Guerin, S., and Moore, D. D. (1988). Two mechanisms for extinction of gene expression in hybrid cells. Science 241, 1205-1207. Tsukada, T., Fink, J. S., Mandel, G., and Goodman, R. H. (1987). Identification of a region in the human vasoactive intestinal polypeptide gene responsible for regulation by CAMP. J. Biol. Chem. 262, 87438747.

Weih, F., Stewart, A. F, and Schütz, G. (1988). A novel and rapid method to generate single stranded DNA probes for genomic footprint. ing. Nucl. Acids Res. 16, 1628.

Yamamoto, K. K., Gonzalez, G. A., Biggs, W. H., III, and Montminy, M. R. (1988). Phosphorylation-induced binding and transcriptional efficacy of nuclear factor CREB. Nature 334, 494498.

Yee, J.-K. (1989). A liver-specific enhancer in the core promoter region of human hepatitis $B$ virus. Science $246,658-661$.

Yu, H., Porton, B., Shen, L., and Eckhardit, L. A. (1989). Role of the octamer motif in hybrid cell extinction of immunoglobulin gene expression: extinction is dominant in a two enhancer system. Cell $58,441-$ 448

Zaller, D., Yu, H., and Eckhardt, L. (1988). Genes activated in the presence of an immunoglobulin enhancer or promoter are negatively regulated by a T-lymphoma cell line. Mol. Cell. Biol. 8, 1932-1939

\section{Note Added in Proof}

The paper referred to throughout as D. Nitsch, A. F. Stewart, M. B., R. Mestril, F. W., and G. S. (submitted) is now in press: Nitsch, D., Stewart, A. F., Boshart, M., Mestril, R., Weih, F., and Schütz, G. (1990). Chromatin structures of the rat tyrosine aminotransferase gene relate to the function of its cis-acting elements. Mol. Cell. Biol. 10, in press. The paper referred to throughout as F. W. A. F. Stewart, M. B., D. Nitsch, and G. S. (submitted) is now in press: Weih, F., Stewart, A. F., Boshart. M. Nitsch_D and Shütz G. (1990) In vivo monitorino of a 